\title{
Life form and species diversity on abandoned croplands,
}

Roggeveld, South Africa

H. van der Merwe* and M.W. van Rooyen

Department of Plant Science, University of Pretoria, Pretoria, 0002, Republic of South Africa

*P.O. Box 1, Calvinia, 8190, Republic of South Africa

e-mail: soekop@hantam.co.za, Tel/Fax:+27 273412578.

* Corresponding author

Running title: Abandoned croplands life form \& species diversity 


\section{Abstract}

The Roggeveld consists of an island of Mountain Renosterveld (Fynbos Biome) surrounded by Succulent Karoo Biome vegetation. Since management of abandoned croplands depends on a better understanding of their succession sequences, vegetation recovery on abandoned croplands in the Roggeveld was studied using species and life form diversity parameters. Abandoned croplands of different ages were compared with each other and to the natural vegetation.

Therophytes and chamaephytes were the most abundant life forms. Chamaephytes made an overwhelming contribution to the relative cover. Species-area curves (exponential function) differed significantly between the abandoned croplands and natural vegetation. Species richness increased with time since abandonment but no similar increase in species evenness, Shannon or Simpson indices were found. A regression of species richness against age of abandoned cropland predicted that an abandoned cropland of approximately 33-years should be as species rich as the natural vegetation, however a Principal Co-ordinate Analysis of floristic data indicated that all the plots were floristically still extremely different from the natural vegetation. Across all nine survey plots only 15 species contributed to a high cover on the plots.

Vegetation recovery on abandoned croplands in the Roggeveld occurs naturally, yet the rate of recovery varies among the life forms.

Keywords: Diversity indices, Fynbos Biome, old fields, species richness, Succulent Karoo Biome 


\section{Introduction}

The Cape Floristic Region (CFR) of South Africa has one of the highest species densities and levels of endemism, at both local and regional scales, for any temperate or tropical continental region (Cowling et al. 1989, Cowling et al. 1992). This region is also recognised as a global hotspot of biodiversity (Cowling \& Hilton-Taylor 1994). The Fynbos Biome, as delineated by Rutherford and Westfall (1994), constitutes the major part of the CFR. This biome comprises three quite different, naturally fragmented vegetation types, namely fynbos, renosterveld and strandveld, that occur in winter- and summer-rainfall areas and are dominated by small-leaved, evergreen shrubs whose regeneration is intimately linked to fire (Rebelo et al. 2006). Renosterveld is one of the most threatened vegetation types in South Africa as a result of transformation by agriculture, alien invasive plants and urbanisation (Rebelo 2001, Rouget et al. 2006). The degree of transformation is strongly linked to topography and geographical location (Rebelo et al. 2006) with the lowlands usually showing a higher degree of transformation than the uplands mainly because the lowlands are more favourable for agriculture and urbanisation. Certain high-lying areas such as the Outeniqua and Tsitsikamma Mountains are, however vulnerable to transformation due to afforestation (Rebelo et al. 2006).

The vegetation of the Roggeveld mountain range was classified as renosterveld vegetation by Low and Rebelo (1996), Mucina et al. (2005) and Van der Merwe et al. (2008). This Mountain Renosterveld on the Roggeveld mountain range therefore constitutes an island of Fynbos Biome vegetation surrounded by the Succulent Karoo Biome. Although it is classified as part of the renosterveld vegetation (Fynbos Biome), it lies on the arid extreme of this vegetation type and differs from other renosterveld vegetation types further south in exhibiting many karroid properties.

Among the earliest references to the botanical wealth of the Mountain Renosterveld date from the early 1900s when Diels (1909) mentioned the 
presence of the Cape element in the flora and the high levels of endemism on the Hantam Mountain. Weimarck (1941) who proposed a classification of the Cape species into five phytogeographical groups treated the HantamRoggeveld as a subcentre of his North-Western Centre and stated that the subcentre constituted the last outlier of the Cape element in the inner parts of western South Africa. The Roggeveld was also one of the three centres of endemism that Hilton-Taylor (1994) identified within the Western Cape Domain, however, he considered the Western Cape Domain as part of the Succulent Karoo Biome.

The dominant shrub, Dicerothamnus rhinocerotis, renosterbos, after which the renosterveld is named, is an indigenous species with encroaching properties. Disturbed areas are quickly colonised and dominated by $D$. rhinocerotis, which is considered disadvantageous from an agricultural point of view since it is not grazed (Shearing 1997). Historical records of early explorers indicate that renosterveld had abundant grasses and that as a result of high grazing pressure renosterbos was increasing in abundance and grasses becoming scarcer (transcriptions and translation of R.J. Gordon's travels, Cullinan 2003). The dominance of $D$. rhinocerotis was also mentioned by Marloth in 1908 who suggested that the frequent burning of vegetation by the early settlers to increase palatable vegetation available for their livestock actually increased the dominance of $D$. rhinocerotis. Marloth (1908) also mentions the monocultures of renosterbos on abandoned croplands and that within the first winter of land abandonment $D$. rhinocerotis seedlings colonise abandoned croplands and that the plants grow prolifically and become denser.

The first European farmers settled along the northern slopes of the Roggeveld mountains in the 1740s (Van der Merwe 1938). These settlements were restricted to the valleys and mountainous regions where permanent water could be found (Van der Merwe 1938, Van der Merwe 1988). These first farmers cultivated crops on a small scale to be self-sustainable. During his travels to the region in 1778 Gordon (Cullinan 2003) noted that he saw planted trees, vegetables and garden fruit. 
The higher rainfall of the Roggeveld in comparison to the surrounding Succulent Karoo areas has allowed farmers to plough large tracts of land to cultivate crops. Numerous utilised and abandoned croplands lie scattered throughout the Roggeveld landscape. Production costs have increased substantially over the years and farmers have been forced to cultivate fewer fields on their lands. This worldwide trend of the increased level of land abandonment is primarily as a result of environmental and socio-economic changes (Cramer et al. 2007).

In semi-arid to arid regions studies on secondary succession are rather scarce, possibly because succession proceeds very slowly under these harsh conditions (Otto et al. 2006), while our knowledge on secondary old field succession in semi-arid Mediterranean environments is extremely poor (Martínez-Duro et al. 2010). However, plant community succession is one of the most important aspects of vegetation ecology (Zhang 2005) since successional plant communities provide a model system for testing a variety of ecological hypotheses regarding the controls on biodiversity that could be applied to the management and restoration of plant communities (Huberty et al. 1998). It is important to know what kind of vegetation can spontaneously develop on abandoned croplands since it determines their further management (Cseeserits et al. 2007). Additionally, with the current predictions of climate change the study of plant succession and vegetation recovery take on an even stronger urgency (Bazzaz 2000). Climate change may alter vegetation dynamics (succession) pathways both by favouring different functional groups of plants and by effects on soil moisture availability or the regimes of wind or fire generated disturbance (Pickett et al. 2009).

The aim of the current study was to use a space-for-time approach to follow the recovery of the vegetation on abandoned croplands in the Roggeveld and to evaluate the rate of recovery in terms of the species composition and various parameters of species and life form diversity. Biodiversity parameters such as species richness, evenness and the Shannon and Simpson indices were used to gain a better understanding of the process of recovery and how the abandoned croplands compare with the original natural vegetation. 


\section{Study area}

The study was carried out on the farm Soekop (32 $02^{\prime} 10.1^{\prime \prime} S$ and $20^{\circ} 07^{\prime}$ 06.9" E) in the Mountain Renosterveld vegetation of the Roggeveld (Figure 1). The Roggeveld mountain range forms the steep escarpment which separates the low-lying Tanqua Karoo basin from the interior plateau of South Africa. Rocks of the Ecca group cover most of the Roggeveld Mountains (Rubidge \& Hancox 1999) with the study area belonging to the Waterford Formation which consists of sandstone, rhythmite, shale and mudstone with wave marks and slumping being common features (Council for Geoscience 2008). Shallow stony lithosol soils are characteristic of the Roggeveld (Francis et al. 2007).

Rainfall in the study area ranges from $132 \mathrm{~mm}$ to $467 \mathrm{~mm}$ per year (Weather Bureau 1998) and although it falls mainly in winter it does include a few summer thunderstorms. In the winter, snowfalls occur with a mean of six snow days recorded per year over a 24-year period by the Weather Bureau (1998). At Sutherland, the mean daily minimum temperature for the coldest month, July, is $-2.4^{\circ} \mathrm{C}$, while the extreme minimum, $-13.6^{\circ} \mathrm{C}$, was recorded in July 1970 and August 1978 (Weather Bureau 1998). The mean daily maximum for the warmest month, January, is $27.1^{\circ} \mathrm{C}$, while the extreme maximum recorded was $35.5^{\circ} \mathrm{C}$ in January 1980 (Weather Bureau 1998).

The study area falls within the Roggeveld Shale Renosterveld vegetation type of Mucina et al. (2005; Rebelo et al. 2006). A recent finer scale classification and mapping of the vegetation associations of the area indicates that the study area falls within the Dicerothamnus rhinocerotis Mountain Renosterveld vegetation association (Van der Merwe et al. 2008). This vegetation association is dominated by a high cover of $D$. rhinocerotis while Merxmuellera stricta and Dimorphotheca cuneata also characterise the vegetation unit. Strong annual and geophyte components in spring are usually present following good winter rains.

\section{Materials and Methods}


Nine (OL 1-9) sample plots using Whittaker's plant diversity plot technique (Shmida 1984) were surveyed. Eight (OL 1-8) of these were surveyed on abandoned croplands of various ages (3-, 4-, 8-, 10-, 15- and 20-years old) with replicates of abandoned croplands aged 3- and 4-years old. Additionally, a plot in the undisturbed natural vegetation close to the abandoned cropland of 20-years old was surveyed (OL 9). All surveys were conducted in 2005 on one farm in the same vegetation type and on the same geological substrate. Furthermore, the surveys were all conducted in spring.

The main reasons for using the Whittaker plot technique were to facilitate comparisons with other diversity studies as well as the ease with which the plot can be set up and sampled relative to other techniques such as the Modified Whittaker Nested Vegetation Sampling Technique of Stohlgren et al. (1995). Stohlgren et al. (1995) found that their long-thin plot design was cumbersome for field crews, and the increase in perimeter to area ratio of the subplots made it more difficult for field crews to identify which plants should be included or excluded. Also, Wilson and Shmida (1984) concluded that the Whittaker method came close to fulfilling four criteria of 'good' performance of beta diversity measures.

The only modification of the methodology described by Shmida (1984) related to the field form and notations used on the field form. A separate column for each size quadrat was provided for on the field form. Additionally, the vegetation of the two $5 \mathrm{~m}^{2}$ quadrats were noted in two separate columns and the $10 \mathrm{~m} \times 10 \mathrm{~m}$ square was separated into two $5 \mathrm{~m} \times 10 \mathrm{~m}$ rectangles and the species were noted apart from one another in two columns on the field form. The columns thus read as follows: ten $1 \mathrm{~m}^{2}$, two $5 \mathrm{~m}^{2}$, two $50 \mathrm{~m}^{2}$ and one $1000 \mathrm{~m}^{2}$ columns. The presence of each species encountered in a quadrat was noted within each column and a percentage cover value given for each species in the $1000 \mathrm{~m}^{2}$ quadrat.

By ensuring that each column contained a list of all species present in that quadrat, more freedom was gained to calculate the number of species present 
in a quadrat of a different size than actually measured. For example, if the number of species for a $15 \mathrm{~m}^{2}$ quadrat is required, the total number of different species across, for example, the ten $1 \mathrm{~m}^{2}$ and a one $5 \mathrm{~m}^{2}$ quadrat could be tallied.

Species encountered in the surveys were separated into broad life form categories following Raunkiaer (1934) as modified in Mueller-Dombois and Ellenberg (1974). These broad life form categories are as follows: (a) phanerophytes, plants that grow taller than $50 \mathrm{~cm}$, or whose shoots die back periodically to that height limit; (b) chamaephytes, plants whose mature branch or shoot system remains perennially within $50 \mathrm{~cm}$ above ground surface, or plants that grow taller than $50 \mathrm{~cm}$, but whose shoots die back periodically to that height limit; (c) hemicryptophytes, perennial (including biennial) herbaceous plants with periodic shoot reduction to a remnant shoot system that lies relatively flat on the ground surface; (d) cryptophytes (geophytes), perennial (including biennial) herbaceous plants with periodic shoot reduction of the complete shoot system to storage organs that are imbedded in the soil; (e) therophytes, annual plants whose shoot and root systems dies after seed production and which complete their whole life cycle within one year; (f) lianas, plants that grow by supporting themselves on others and (g) parasites, heterotrophic plants, vascular plants growing on living plants. The relative contributions of each life form, in terms of species as well as plant cover, to the $1000 \mathrm{~m}^{2}$ sample plots were calculated.

The total species number for seven plot sizes $\left(1 \mathrm{~m}^{2}, 5 \mathrm{~m}^{2}, 10 \mathrm{~m}^{2}, 20 \mathrm{~m}^{2}, 50\right.$ $\mathrm{m}^{2}, 100 \mathrm{~m}^{2}$ and $1000 \mathrm{~m}^{2}$ ) were determined. These seven plot sizes were used to construct Type II species-area curves (Scheiner 2003, Scheiner 2004) for each of the nine plots sampled using the exponential function since this function produced the best results in a study across the entire HantamTanqua-Roggeveld subregion (Van der Merwe 2009, Van der Merwe \& Van Rooyen 2011a). The exponential function is expressed as a semilog function:

$$
S=z \times \log A+c(\text { Veech 2000), }
$$

where: $\quad S=$ species richness

$A=$ area of survey plot 
$\mathrm{z}$ and $\mathrm{c}$ are constants.

Species richness (S), Shannon's index of diversity (H'), Simpson's index (D) and a measure of evenness $(E)$ were calculated for each sampled plot at the $1000 \mathrm{~m}^{2}$ (0.1 ha) size, using the PC-ORD computer program (PC-ORD Version 4 for Windows, MjM Software design) which calculates these four diversity measures as follows:

$S=$ richness $=$ number of species.

$$
\begin{aligned}
& H^{\prime}=\text { Shannon diversity } \\
& H^{\prime}=-\sum p_{i} \log p_{i}
\end{aligned}
$$

Where $p_{i}=$ importance probability in column $i$.

$E=$ Evenness (equitability) = H' / In (richness).

$D=$ Simpson's index of diversity for an infinite population. This is the complement of Simpson's original index and represents the likelihood that two randomly chosen individuals will be different species.

$$
\mathrm{D}=1-\sum p_{i}
$$

The Shannon index was also used to calculate a life form diversity index using frequencies of life forms instead of species.

The Chi-square test of the STATISTICA computer package (StatSoft, Inc. Version 8, 2300 East $14^{\text {th }}$ Street, Tulsa, OK 74104) was used to compare the life-form distributions. Floristic data for all nine plots surveyed were ordinated using Principal Co-ordinate Analysis (PCoA) in the SYN-TAX computer program (Podani 2001) because the use of a wide array of distance measures in Principal Co-ordinate Analysis (PCoA) can give a marked improvement over Principal Component Analysis (PCA) (McCune \& Grace 2002). The 
statistical significance of the differences between slope values and intercepts of the exponential function curves were analysed by an Analysis of Covariance (Quinn \& Keough 2002) linear regression with GraphPad Prism 4.03 for Windows (GraphPad software, San Diego, California, USA, www.graphpad.com.).

\section{Results and discussion}

Whittaker's plant diversity plot technique has proved to be an efficient method of sampling used around the world, especially in semi-arid environments (Shmida 1984, Van der Merwe 2009, Van der Merwe \& Van Rooyen 2011a). The data derived by this technique were used to determine various life form and species diversity parameters for abandoned croplands of various ages in the Roggeveld. These data were compared to baseline data of the various plant diversity parameters determined for the Roggeveld area using the same technique (Van der Merwe 2009, Van der Merwe \& Van Rooyen (in press)).

The tradition of classifying plants and vegetation into major types on the basis of plant form has a long history (Vandvik \& Birks 2002). The life form of a species refers to the vegetative form of the plant body and it is assumed to be a result of morphological adjustment to the climate and environment (Cain 1950, Barkman 1979, Van Rooyen et al. 1990, Semenova \& Van der Maarel 2000). Cain (1950) stated that the spectra for successional communities of various sorts might reflect edaphic conditions and give a good measure of the changing environment as succession proceeds. When considering the abundance of each life form at $1000 \mathrm{~m}^{2}$ (Figure 2) and the contribution per life form expressed as a percentage of the total number of species (Figure 3), trends along the successional sequence are observed.

Generally, therophyte and chamaephyte species were the most abundant species throughout the various stages of secondary succession in the Roggeveld (Figure 2b, 2e, 3). Therophyte species increased in number with age of the abandoned croplands up to croplands last ploughed 8-years ago and with a noticeable decrease in number found on the abandoned croplands 
of 10 -years and older (Figure $2 \mathrm{e}, 3$ ) and in the natural vegetation. The relative contribution of therophyte species to the life form distribution demonstrated the same trend except for the 3-year old abandoned croplands where they constituted almost half of the species (Figure 3). Chamaephyte species generally increased in number as the age of the abandoned croplands increased, with the natural vegetation holding the highest number of chamaephyte species (Figure 2b). However, the relative contribution of chamaephyte species showed no trend (Figure 3).

Cryptophyte (geophyte) species generally increased gradually along the time scale since abandonment (Figure 2d) however, the relative contribution of cryptophyte species to the 20-year old abandoned cropland was still less than half the relative contribution to the natural vegetation (Figure 3). Different life forms have different sensitivities to soil disturbance (McIntyre et al. 1995) and cryptophyte species are severely depleted by continuous ploughing to produce crops. These effects of cultivation still prevail in the species composition on the abandoned croplands (Stromberg \& Griffin 1996) and was particularly evident in the current study when considering the rich geophytic component of the Roggeveld (Van Wyk \& Smith 2001).

The small number and relative abundance of hemicryptophyte species increased with age since land abandonment (Figure 2c, 3). Phanerophyte numbers remained relatively constant throughout all the plots of varying ages (Figure 2a, 3). This could be ascribed to the ability of Dicerothamnus rhinocerotis to quickly colonise disturbed areas throughout the Roggeveld region. Liana species were only present in abandoned croplands of 10-years and older (Figure $2 f, 3$ ). No parasite species were encountered in any of the plots surveyed.

Therophyte species were initially replaced predominantly by chamaephyte species and in later successional ages by a combination of chamaephyte and cryptophyte species. This replacement of therophyte species with mainly chamaephyte species differs from the 'classical' sequence of life forms on old fields where the annual species are replaced by biennials and herbaceous 
perennials (i.e. hemicryptophytes) before these are replaced by chamaephytes and eventually phanerophytes (Debussche et al. 1996, Huberty et al. 1998, Otto et al. 2006). However, which mechanisms of species replacement operate at a particular time and place in succession depends largely on the growth form of the dominant species of the site (e.g. annual vs. perennial life cycle, canopy-forming vs. understorey species, clonal vs. nonclonal). Species replacement also depends on the life history characteristics, dispersal mode and growth form of the potential occupants of the site and the nature of natural disturbances (Armesto \& Pickett 1986, Dölle et al. 2008). Considering that the Roggeveld vegetation is generally rich in chamaephyte and cryptophyte species and poor in phanerophyte and hemicryptophyte species, the successional transition from therophyte species to chamaephyte species and later a combination of chamaephyte and cryptophyte species can be understood.

By weighting every species by its relative cover and expressing this value as a percentage of the total relative cover, a very different life form distribution is obtained (Figure 4). Phanerophyte contribution decreased from the 3- to 8year old abandoned croplands, then increased substantially on the 10-year old abandoned cropland and decreased again to the 20-year old abandoned cropland, thereafter remaining at a slightly increased lower level (Figure 4). The dominant life form, contributing to the highest cover, is the chamaephyte life form. Chamaephytes comprise a third of the vegetation cover on 3-year old abandoned croplands and continually increased in cover to a value of $80.3 \%$ on 20-year old abandoned croplands, with the natural vegetation holding $70.9 \%$ chamaephyte cover (Figure 4). Hemicryptophytes increased after three years of abandonment thereafter remaining relatively constant throughout all the abandoned croplands (Figure 4). The relative contribution of cryptophytes (geophytes) to vegetation cover increased from the third year of abandonment and varied within a narrow band throughout the abandoned croplands, with the cryptophytes contributing to a higher cover $(8.2 \%)$ in the natural vegetation (Figure 4). Therophytes' contribution to the total cover was highest during the first 8-years of cropland abandonment and decreased noticeably on the 10-year old abandoned cropland and remained at this lower 
level, which was similar to its contribution in the natural vegetation (Figure 4). The smallest contribution to total cover of any life form was that of the lianas which remained $\leq 0.6 \%$ of the total cover (Figure 4 ).

The Chi-squared test comparing the life form spectra on a species basis of the natural vegetation with the 3-, 4- and 8-year old abandoned croplands produced highly significant differences $(p<0.001)$. No significant differences were found between the natural vegetation and abandoned croplands of 10 and 20-years old however, a significant difference $(p<0.05)$ was found between the natural vegetation and the 15-year old abandoned cropland.

Species-area curves were constructed using the exponential function because this function generally performs well (Connor \& McCoy 1979, Tjørve 2003) and was also found to produce the best fit in a study of the natural vegetation of the Hantam-Tanqua-Roggeveld (Van der Merwe \& Van Rooyen 2011a). Contrary to general theoretical expectations about species/area relationships, Bazzaz (2000) found that species number in successional habitats rarely rises smoothly and asymptotically with an increase in area because patchiness in the distribution of resources and species can generate abrupt changes in species/area relations. However, in this study no sudden increases in species number were evident and in all cases an asymptote seemed to be reached. $\mathrm{A}$ comparison of the slope and intercept values of the exponential curves between the abandoned croplands and the natural vegetation found that the curve for the natural vegetation was always significantly different from that of the abandoned croplands (Table 1). In most cases the slopes were different, but whenever the slope values were not different the intercept values were found to be significantly different.

Species richness, or the number of species, is currently the most widely used diversity measure (Stirling \& Wilsey 2001) and is used extensively in secondary succession literature (Squiers \& Wistendahl 1976, Inouye et al. 1987, Lavorel 1994, Prieur-Richard et al. 2000, Tunnell et al. 2004, Gibson et al. 2005, Zhan et al. 2007) in comparisons between abandoned croplands of various ages and the natural vegetation to indicate the degree of recovery. 
Generally, the species richness values acquired in this study for the abandoned croplands indicate the expected low species richness on abandoned croplands of three to four years in age (20 to 33 species per $1000 \mathrm{~m}^{2}$, Table 2). There is a marked increase in species richness at the ages between eight and 20 years (40 to 48 species per $1000 \mathrm{~m}^{2}$, Table 2). The undisturbed vegetation close to the 20-year old abandoned cropland had a species richness of 66 per $1000 \mathrm{~m}^{2}$ (Table 2). The latter value compares well with values obtained for other natural vegetation in the Roggeveld in which species richness varied from 62 to 100 species per $1000 \mathrm{~m}^{2}$ with a mean value of 79 species per $1000 \mathrm{~m}^{2}$ (Van der Merwe \& Van Rooyen (in press)). A regression of the age of the abandoned cropland against the number of species found per $1000 \mathrm{~m}^{2}$ suggests that theoretically an abandoned cropland of approximately 33 years after abandonment should be as species rich as the natural vegetation (Figure 5). However, such an extrapolation of the regression beyond the actual data points must be viewed with caution.

A measure of species evenness (E) was calculated for each plot sampled. Evenness is constrained between zero and 1.0 with 1.0 representing a situation in which all species are equally abundant (Magurran 1988). Evenness values ranged from 0.573 (OL8, 20-year old) to 0.797 (OL5, 8-year old) with one 3-year old abandoned cropland (OL2, 3-year old) having an evenness value of 0.404 (Table 2). Evenness values on the abandoned croplands were therefore comparable with previously determined values for the Roggeveld, which ranged from 0.501 to 0.820 (Van der Merwe \& Van Rooyen (in press)).

The Shannon indices calculated for the nine plots in this study ranged from 1.211 (OL2, 3-year old) to 3.014 (OL5, 8-year old) (Table 2), whereas values found in a study conducted in the natural vegetation ranged from 2.225 to 3.743 for the Mountain Renosterveld vegetation of the Roggeveld (Van der Merwe \& Van Rooyen (in press)). The Shannon and Simpson indices take both evenness and species richness into account (Magurran 1988). Shannon 
indices showed the same pattern as the evenness values. Simpson indices found for all nine plots surveyed showed little variation and ranged from 0.743 (OL4, 4-year old) to 0.884 (OL5, 8-year old) with the exception of OL2 (3-year old) with a Simpson index of 0.435 (Table 2). Simpson indices for the natural vegetation of the Roggeveld showed a greater variation and ranged from 0.604 to 0.944 (Van der Merwe \& Van Rooyen (in press)).

None of the diversity parameters, species evenness, Shannon or Simpson indices, reflected the trend in species richness, which showed a continuous increase in the number of species. This seems to indicate that although species richness increases, the dominance of a few species also increases disproportionately.

Across all the survey plots 15 species contributed most to the cover found within a plot (Table 3). Eight of these species (Chrysocoma ciliata, Dicerothamnus rhinocerotis, Dimorphotheca cuneata, Euryops laterifolius, Helichrysum hamulosum, Merxmuellera stricta, Oedera genistifolia and Poa bulbosa) also contributed to the high vegetation cover of the natural vegetation. A maximum of five (Chrysocoma ciliata, Dicerothamnus rhinocerotis, Dimorphotheca cuneata, Medicago polymorpha and Selago cf. rigida) of the 15 species contributed a high cover, at any one time, on the abandoned croplands. Four of the seven annual species with the highest abundances were abundant only on the abandoned croplands up to an age of 8-years, these species were Cotula nudicaulis, Hordeum murinum, Karoochloa tenella and Medicago polymorpha. Thus, no annuals at high abundances were found on abandoned croplands of 10-years and older. Furthermore, the two introduced weedy species (Hordeum murinum and Medicago polymorpha) were virtually absent on croplands of 10-years and older. The perennial component cover varied greatly across all the surveyed plots. All eight perennial species with the highest abundances were present in the natural vegetation, which confirms the statement by Van der Putten et al. (2000) that in succession the identity of the local species matter. These results support the findings of Cayuela et al. (2008) who found that the initial differences in species composition persisted in time. Such results are 
consistent with the hypothesis of initial floristic composition (Egler 1954), which states that those species present at a particular site early in succession pre-empt the site and influence the course of succession on it for a long time (Cayuela et al. 2008). The fact that three of the perennial species were present from the very early stages of succession also seems to support the tolerance and not facilitation model of Connell and Slatyer (1977; Gurevitch et al. 2002).

To analyse floristic patterns with respect to the data of the nine survey plots a Principal Co-ordinate Analysis (PCoA) was done. The resulting PCoA shows the relatively close proximity of the younger abandoned croplands (3-, 4- and 8 -years old) to the older abandoned croplands (10-, 15- and 20-years old) and the large floristic gap between these abandoned croplands and the natural vegetation (OL9) (Figure 6). Thus, even although the regression of the age of abandoned cropland and number of species per $1000 \mathrm{~m}^{2}$ indicates that after approximately 33-years an abandoned cropland will be as species rich as the natural vegetation (Figure 5) floristically, this abandoned cropland will still be appreciably different from the natural vegetation (Figure 6).

Having no replicate plots for abandoned croplands of 8-, 10-, 15- and 20 years old also might have biased the species richness values and time needed to return the disturbed vegetation to its natural state. However, this was unavoidable since no such replicates of abandoned croplands of these ages under the same environmental conditions were available on the farm which is managed as a single unit.

When comparing the position of the natural vegetation with the abandoned croplands it is implied that succession proceeds on a single set pathway and that it leads to a predictable stable community. However, large variability in the recovery of the vegetation is likely to be found. Differences among fields may be due to pre-abandonment treatments, such as the type of crop or cultivation practice, climatic conditions after abandonment or grazing management. Cramer and Hobbs (2007) stated that within limitations imposed by climate and soil characteristics, it does appear that the combination of past 
land use type and land use intensity explains much of the difference in patterns within similar ecosystem types.

The 2005 year in which these data were collected was a poor rainfall year. This is expected to have underestimated the number of species, especially with respect to annuals and geophytes, which comprise a large part of the species diversity in the region. Thus the species richness values for both the abandoned croplands and the undisturbed vegetation are expected to be higher than the values reported here. Additional annuals would have affected both the abandoned croplands and the natural vegetation species richness values, whereas the geophytic component would have had a larger impact on the natural vegetation survey data.

The pattern of recovery of Roggeveld Mountain Renosterveld seems to differ from the West Coast Renosterveld of the Cape Floristic Region which implies different management procedures in both these areas. Studies conducted on Elandsberg Private Nature Reserve on remnant renosterveld vegetation and abandoned croplands indicated the apparent slow return of indigenous renosterveld vegetation on abandoned croplands (Midoko-lponga et al. 2005). The main difference between the two areas is the dominance by introduced alien annual grasses on abandoned croplands in the West Coast Renosterveld. These weedy grasses arrest the whole recovery process. Current restoration efforts aim to reduce the cover of the introduced grasses while at the same time maintaining or even increasing species richness and diversity of indigenous target species (Krug \& Krug 2007). In spite of the Roggeveld probably having harsher environmental conditions, recovery on abandoned croplands is occurring and seems to be continuing with a steady increase in species richness occurring and values of evenness, Shannon and Simpson indices of diversity being similar to those of the natural vegetation from approximately 10 years after abandonment.

All life forms are well represented within 20-years of cropland abandonment, however cryptophyte species are still underrepresented. This is to be expected since these species are eradicated by ploughing and reproduction, 
by vegetative means or seed set, occurs slowly. Geophyte species are an important component of the Roggeveld flora and from a diversity point of view, the return of these species on abandoned croplands is important.

No fires were experienced on any of the surveyed abandoned croplands, but it is expected that fire would simply slow down secondary succession with early successional species such as Dicerothamnus rhinocerotis, Chrysocoma ciliata and Dimorphotheca cuneata re-establishing within the next growing season. This is supported by data collected on post-fire monitoring plots in the Roggeveld that show $D$. rhinocerotis seedlings established in plots within nine months following a fire (Van der Merwe \& Van Rooyen 2011b).

\section{Conclusions}

The Roggeveld, located within the Fynbos Biome, has a higher rainfall than the surrounding areas and has been used to cultivate wheat and other fodder crops for hundreds of years. Primarily due to an increase in production costs, many croplands are no longer utilised and now lie barren.

Chamaephyte and therophyte species were the most abundant life forms on abandoned croplands of all ages while hemicryptophyte, phanerophyte, liana and parasite species were the least abundant life forms. However, liana and parasite species were also seldom found in the natural vegetation.

The relative cover of each life form expressed as a percentage of the total cover indicates the overwhelming contribution made by chamaephytes. Phanerophyte and cryptophyte contributions fluctuated throughout the abandoned cropland succession. Therophyte cover was initially high, thereafter decreasing substantially. Hemicryptophyte and liana cover contributions were negligible.

Comparison of slope and intercept values of the exponential function speciesarea curves across all the abandoned croplands and the natural vegetation found that the curves of the abandoned croplands differed significantly from 
those of the natural vegetation in all instances. Species richness increased with the age of the abandoned cropland, however, a similar increase in the values of evenness, Shannon and Simpson indices were not found. A regression using species richness values on age since abandonment predicted that an abandoned cropland of approximately 33-years should be as species rich as the natural vegetation. Yet, a Principal Co-ordinate Analysis of the floristic data indicated that floristically all the abandoned croplands were still extremely different from the natural vegetation.

Across all the survey plots, 15 species contributed most to the high cover with eight of these also contributing to the high cover of the natural vegetation. Four annual species were present in high abundances on abandoned croplands of $\leq 8$-years of age, with no indigenous or alien invasive annual species at high abundances on older abandoned croplands. The perennial component cover varied greatly across all the surveyed plots.

The Roggeveld Mountain Renosterveld abandoned croplands surveyed were not negatively influenced by alien annual grasses as in the West Coast Renosterveld and species richness increased continually. Recovery of abandoned croplands seems to occur naturally, however after 20-years, cryptophyte species were still largely underrepresented in comparison to the natural vegetation. It is expected that the influence of fire would simply slow down secondary succession with early colonisers establishing again by the next growing season.

The results of this study contribute to our understanding of succession and restoration efforts on abandoned croplands in the Roggeveld and can be used to guide the management of abandoned croplands in the region.

\section{Acknowledgements}

The authors would like to thank the Critical Ecosystem Partnership Fund (CEPF) through the Succulent Karoo Ecosystem Plan/Program (SKEP) initiative for funding the project. The Critical Ecosystem Partnership Fund is a 
joint initiative of Conservation International, the Global Environmental Facility, the Government of Japan, the MacArthur Foundation and the World Bank. A fundamental goal is to ensure civil society is engaged in biodiversity conservation. The various people who assisted with the field work are gratefully acknowledged. This research was supported by the National Research Foundation under grant number 61277.

\section{References}

Armesto JJ, Pickett STA. 1986. Removal experiments to test mechanisms of plant succession in old fields. Vegetatio 66: 85-93.

Barkman JJ. 1979. The investigation of vegetation texture and structure. In: Werger MJA (ed.), The study of vegetation. Junk, London. pp 125-160.

Bazzaz FA. 2000. Plants in changing environments. Linking physiological, population and community ecology. Cambridge University Press, Cambridge.

Cain SA. 1950. Life-forms and phytoclimate. The Botanical Review 16: 1-32.

Cayuela L, Rey Benayas JM, Maestre FT, Escudera A. 2008. Early environments drive diversity and floristic composition in Mediterranean old fields: insights from a long-term experiment. Acta Oecologica 34: 311-321.

Connell JH, Slatyer RO. 1977. Mechanisms of succession in natural communities and their role in community stability and organisation. The American Naturalist 111: 1119-1144.

Connor EF, McCoy ED. 1979. The statistics and biology of the species-area relationship. The American Naturalist 113: 791-833.

Council for Geoscience 2008. Geological data 1: 250 000. CD data provided by the Council for Geoscience, Silverton, Pretoria.

Cowling RM, Gibbs Russel GE, Hoffman MT, Hilton-Taylor C. 1989. Patterns of plant species diversity in southern Africa. In: Huntley BJ (ed.), Biotic diversity in southern Africa. Concepts and Conservation. Oxford University Press, Cape Town. pp 19-50.

Cowling RM, Hilton-Taylor C. 1994. Patterns of plant diversity and endemism in southern Africa: an overview. In: Huntley BJ (ed.), Botanical diversity 
in southern Africa. Strelitzia 1. National Botanical Institute, Pretoria. pp 31-52.

Cowling RM, Holmes PM, Rebelo AG. 1992. Plant diversity and endemism. In: Cowling RM (ed.), The Ecology of Fynbos: Nutrients, fire and diversity. Oxford University Press, Cape Town. pp 62-112.

Cramer VA, Hobbs RJ. 2007. Old fields. Dynamics and restoration of abandoned farmland. Island Press, Washington.

Cramer VA, Hobbs RJ, Standish RJ. 2007. What's new about old fields? Land abandonment and ecosystem assembly. Trends in Ecology and Evolution 23: 104-112.

Cseeserits A, Szabó R, Halassy M, Rédei T. 2007. Testing the validity of successional predictions on an old-field chronosequence in Hungary. Community Ecology 8: 195-202.

Cullinan P. 2003. Robert Jacob Gordon 1743 - 1795. The man and his travels at the Cape.

http:// web.uct.ac.za/depts/age/people/Gordon/frameset.htm

Debussche M, José E, Lepart J, Houssard C, Lavorel S. 1996. Changes in Mediterranean plant succession: old-fields revisited. Journal of Vegetation Science 7: 519-526.

Diels L. 1909. Formationen und florenelemente im nordwestlichen Kapland. Botanische Jahrbücher 44: 91-124.

Dölle M, Bernhardt-Römermann M, Parth A, Schmidt W. 2008. Changes in life history trait composition during undisturbed old-field succession. Flora 203: 508-522.

Egler FE. 1954. Vegetation science concepts. I. Initial floristic composition - a factor in old-field vegetation development. Vegetatio 4, 412-418.

Francis ML, Fey MV, Prinsloo HP, Ellis F, Mills AJ, Medinski TV. 2007. Soils of Namaqualand: Compensations for aridity. Journal of Arid Environments 70: 588-603.

Gibson DJ, Middleton BA, Foster K, Honu YAK, Hoyer EW, Mathis M. 2005.

Species frequency dynamics in old-field succession: effects of disturbance, fertilization and scale. Journal of Vegetation Science 16: 415-422. 
Germishuizen G, Meyer NL. 2003. Plants of southern Africa: an annotated checklist. Strelitzia 14. National Botanical Institute, Pretoria.

Gurevitch J, Scheiner SM, Fox GA. 2002. The Ecology of Plants. Chapter 13.

Disturbance and Succession. Sinauer, Massachusetts, U.S.A. pp 253274.

Hilton-Taylor C. 1994. Western Cape Domain (Succulent Karoo). In: Davis $\mathrm{SD}$, Heywood VH, Hamilton AC (eds), Centres of plant diversity. A guide and strategy for their conservation. IUCN Publications Unit, Cambridge. pp 201-203.

Huberty LE, Gross KL, Miller CJ. 1998. Effects of nitrogen addition on successional dynamics and species diversity in Michigan old-fields. Journal of Ecology 86: 794-803.

Inouye RS, Huntly NJ, Tilman D, Tester JR, Stillwell M, Zinnel KC. 1987. Oldfield succession on a Minnesota sand plain. Ecology 68: 12-26.

Krug CB, Krug RM. 2007. Restoration of old fields in Renosterveld: a case study in a Mediterranean-type shrubland of South Africa. In: Cramer VA, Hobbs RJ (eds), Old fields. Dynamics and restoration of abandoned farmland. Island Press, Washington. pp 265-285.

Lavorel S, Lepart J, Debussche M, Lebreton J-D, Beffy J-L. 1994. Small scale disturbances and the maintenance of species diversity in Mediterranean old fields. OIKOS 70: 455-473.

Low AB, Rebelo AG. 1996. Vegetation of South Africa, Lesotho and Swaziland. Department of Environmental Affairs and Tourism, Pretoria.

Magurran AE. 1988. Ecological Diversity and its measurement. Cambridge University Press, Cambridge.

Marloth R. 1908. Das Kapland, insonderheit das Reich der Kapflora, das Waldgebiet und die Karoo, pflanzengeografisch dargestellt. Wissenschaftliche Ergebnisse der Deutscher Tiefsee-Expedition 'Waldivia', 1898 - 1899. 2, T. 3, Fischer, Jena.

Martínez-Duro E, Ferrandis P, Escudera A, Luzuriaga AL, Herranz JM. 2010. Secondary old-field succession in an ecosystem with restrictive soils: does time from abandonment matter? Applied Vegetation Science 13: 234-248. 
McCune B, Grace JB. 2002. Analysis of Ecological Communities. MjM Stoftware Design, Gleneden Beach, Oregon.

Mclntyre S, Lavorel S, Tremont RM. 1995. Plant life-history attributes: their relationship to disturbance response in herbaceous vegetation. Journal of Ecology 83: 31-44.

Midoko-Iponga D, Krug CB, Milton SJ. 2005. Competition and herbivory influence growth and survival of shrubs on old fields: implications for restoration of renosterveld shrubland. Journal of Vegetation Science 16: 685-692.

Mucina L, Rutherford MC, Powrie LW. 2005. Vegetation map of South Africa, Lesotho and Swaziland, 1:1000 000 scale sheet maps. South African National Biodiversity Institute, Pretoria.

Mueller-Dombois D, Ellenberg, H. 1974. Aims and methods of vegetation ecology. Wiley, New York.

Otto R, Krüsi BO, Burga CA, Fernándes-Palacios JM. 2006. Old-field succession along a precipitation gradient in the semi-arid coastal region of Tenerife. Journal of Arid Environments 65: 156-178.

Pickett STA, Cadenasso ML, Meiners SJ. 2009. Ever since Clements: from succession to vegetation dynamics and understanding to intervention. Applied Vegetation Science 12: 9-21.

Podani J. 2001. SYN-TAX 2000 Computer programs for data analysis in ecology and systematics. Scientia publishing, Budapest.

Prieur-Richard A-H, Lavorel S, Grigulis K, Dos Santos A. 2000. Plant community diversity and invasibility by exotics: invasion of Mediterranean old fields by Conyza bonariensis and Conyza canadensis. Ecology Letters 3: 412-422.

Quinn GP, Keough MJ. 2002. Experimental design and data analysis for biologists. Cambridge University Press, Cambridge.

Raunkiaer C. 1934. The life forms of plants and statistical plant geography. Oxford University Press, Oxford.

Rebelo AG. 2001. The state of plants in the Cape flora. In: Verdoorn GH, Le Roux J (eds), The state of South Africa's species. Endangered Wildlife Trust, Pretoria. pp 18-43. 
Rebelo AG, Boucher C, Helme N, Mucina L, Rutherford MC. 2006. Fynbos Biome. In: Mucina L, Rutherford MC (eds), The vegetation of South Africa, Lesotho and Swaziland. Strelitzia 19. South African National Biodiversity Institute, Pretoria. pp 52-219.

Rouget M, Jonas Z., Cowling RM, Desmet PG, Driver A, Mohamed B, Mucina L, Rutherford MC, Powrie LW. 2006. Ecosystem status and protection levels of vegetation types. In: Mucina L, Rutherford MC (eds), The vegetation of South Africa, Lesotho and Swaziland. Strelitzia 19. South African National Biodiversity Institute, Pretoria. pp 724-737.

Rubidge BS, Hancox PJ. 1999. The Karoo - a palaeontological wonderland. In: Viljoen MJ, Reimold WU (eds), An introduction to South Africa's geological and mining heritage. Published by the Geological Society of South Africa and Mintek. pp 83-91.

Rutherford MC, Westfall RH. 1994. Biomes of Southern Africa. An objective characterisation. Memoirs of the Botanical Survey of South Africa 63: 1-94.

Scheiner SM. 2003. Six types of species-area curves. Global Ecology and Biogeography 12: 441-447.

Scheiner SM. 2004. A mélange of curves - further dialogue about speciesarea relationships. Global Ecology and Biogeography 13: 479-484.

Semenova GV, Van der Maarel E. 2000. Plant functional types - a strategic perspective. Journal of Vegetation Science 11: 917-922.

Shearing D. 1997. Karoo: South African Wildflower Guide 6. National Book Printers, Drukkery street, Goodwood, Western Cape.

Shmida A. 1984. Whittaker's plant diversity sampling method. Israel Journal of Botany 33: 41-46.

Squiers ER, Wistendahl WA. 1976. Changes in plant species diversity during early secondary succession in an experimental old-field system. The American Midland Naturalist 98: 11-21.

Stirling G, Wilsey B. 2001. Empirical relationships between species richness, evenness, and proportional diversity. The American Naturalist 158: 286-299.

Stohlgren TJ, Falkner MB, Schell LD. 1995. A modified-Whittaker nested vegetation sampling method. Vegetatio 117: 113-121. 
Stromberg MR, Griffin JR. 1996. Long-term patterns in coastal California grasslands in relation to cultivation, gophers, and grazing. Ecological applications 6: 1189-1211.

Tjørve E. 2003. Shapes and functions of species-area curves: a review of possible models. Journal of Biogeography 30: 827-835.

Tunnell SJ, Engle DM, Jorgensen EE. 2004. Old-field grassland successional dynamics following cessation of chronic disturbance. Journal of Vegetation Science 15: 431-436.

Van der Merwe H. 2009. Patterns of plant diversity in the Hantam-TanquaRoggeveld Subregion of the Succulent Karoo, South Africa. PhD thesis, University of Pretoria, Pretoria.

Van der Merwe H, Van Rooyen MW, Van Rooyen N. 2008. Vegetation of the Hantam-Tanqua-Roggeveld subregion, South Africa. Part 1. Fynbos Biome related vegetation. Koedoe 50: 160-183.

Van der Merwe H, Van Rooyen MW. 2011a. Species-area relationships in the Hantam-Tanqua-Roggeveld, South Africa. Biodiversity and Conservation 20:1183-1201.

Van der Merwe H, Van Rooyen MW. 2011b. Vegetation trends following fire in the Roggeveld, Mountain Renosterveld, South Africa. South African Journal of Botany 77:127-136.

Van der Merwe H, Van Rooyen MW. (in press). Guiding conservation efforts in the Hantam-Tanqua-Roggeveld (South Africa) using diversity parameters. Koedoe (in press).

Van der Merwe PJ. 1938. Die trekboer in die geskiedenis van die Kaapkolonie (1657-1842). Nasionale Pers Beperk, Kaapstad.

Van der Merwe PJ. 1988. Die noordwaartse beweging van die boere voor die Groottrek (1770-1842). The State Library, Pretoria.

Van der Putten WH, Mortimer SR, Hedlund K, Van Dijk C, Brown VK, Lepš J, Rodrigues-Barrueco C, Roy J, Diaz Len TA, Gromsen D, Korthals GW, Lavorel S, Santa Regina I, Smilauer P. 2000. Plant species diversity as a driver of early succession in abandoned fields: a multi-site approach. Oecologia 124: 91-99. 
Vandvik V, Birks HJB. 2002. Pattern and process in Norwegian upland grasslands: a functional analysis. Journal of Vegetation Science 13: 123-134.

Van Rooyen MW, Theron GK, Grobbelaar N. 1990. Life form and dispersal spectra of the flora of Namaqualand, South Africa. Journal of Arid Environments 19: 133-145.

Van Wyk AE, Smith GF. 2001. Regions of Floristic Endemism in Southern Africa: A review with emphasis on succulents. Umdaus Press, Pretoria. pp 1-199.

Veech JA 2000. Choice of species-area function affects identification of hotspots. Conservation Biology 14: 140-147.

Weather Bureau 1998. Climate of South Africa. Climate statistics up to 1990. WB 42. Government Printer, Pretoria.

Weimarck H. 1941. Phytogeographical groups, centres and intervals within the Cape flora. Lunds Universitets Arsskrif Avd. 2. 37: 1-143.

Wilson MV, Shmida A. 1984. Measuring Beta diversity with presence-absence data. Journal of Ecology 72: 1055-1064.

Zhan X, Li L, Cheng W. 2007. Restoration of Stipa kryloviisteppes in inner Mongolia of China: assessment of seed banks and vegetation composition. Journal of Arid Environments 68: 298-307.

Zhang J-T. 2005. Succession analysis of plant communities in abandoned croplands in the eastern Loess plateau of China. Journal of Arid Environments 63: 458-474. 


\section{Table headings and Figure Captions:}

Table 1. Age of the abandoned cropland, survey plot number, exponential function, $r$-value and $p$-value (significance of fit) for the species-area curve for the plots surveyed on abandoned croplands of various ages and in the natural vegetation. The statistical significance of the comparisons of slope and intercept values between each abandoned cropland with the natural vegetation is also provided

Table 2. Age of abandoned cropland, survey plot number, species richness, species evenness, Shannon's index of diversity and Simpson's index for abandoned croplands of different ages and the natural vegetation in the Roggeveld

Table 3. The percentage cover of the 15 most abundant species in abandoned croplands of various ages and in the natural vegetation in the Roggeveld

Figure 1. The location of the study site within the Roggeveld mountain range.

Figure 2. Total number of species per life form in $1000 \mathrm{~m}^{2}$ plots on abandoned croplands of various ages and the natural vegetation in the Roggeveld for the following life forms: a) phanerophytes, b) chamaephytes, c) hemicryptophytes, d) cryptophytes, e) therophytes and f) lianas.

Figure 3. Number of species per life form per $1000 \mathrm{~m}^{2}$ expressed as a percentage of the total number of species across the abandoned croplands of various ages and the natural vegetation in the Roggeveld.

Figure 4. Relative cover per life form expressed as a percentage of the total cover across the abandoned croplands of various ages and the natural vegetation in the Roggeveld. 
Figure 5. Regression of the number of species per $1000 \mathrm{~m}^{2}$ ( $\left.0.1 \mathrm{ha}\right)$ on the age of abandoned cropland.

Figure 6. Principal Co-ordinate Analysis (PCoA) of the floristic data of the abandoned croplands (1-8) and the natural vegetation (9). 
Table 1.

\begin{tabular}{|c|c|c|c|c|c|c|}
\hline \multirow[t]{2}{*}{$\begin{array}{c}\text { Age of } \\
\text { abandoned } \\
\text { cropland }\end{array}$} & \multirow[t]{2}{*}{$\begin{array}{c}\text { Survey } \\
\text { plot } \\
\text { number }\end{array}$} & \multicolumn{3}{|c|}{ Exponential (Semi-log) function } & \multicolumn{2}{|c|}{$\begin{array}{l}\text { Significance of } \\
\text { comparison of } \\
\text { slope and intercept } \\
\text { values between } \\
\text { abandoned } \\
\text { croplands and the } \\
\text { natural vegetation }\end{array}$} \\
\hline & & Linear equation & $\begin{array}{l}\text { r- } \\
\text { value }\end{array}$ & $\mathrm{p}$-value & $\begin{array}{l}\text { Slope } \\
\text { value }\end{array}$ & $\begin{array}{l}\text { Intercept } \\
\text { value }\end{array}$ \\
\hline 3 years & OL1 & $y=1.3686+8.2400 x$ & 0.9621 & $0.0005^{\star * *}$ & $0.0002^{* \star *}$ & \\
\hline 3 years & OL2 & $y=0.4980+5.4866 x$ & 0.9310 & $0.0023^{\star \star}$ & $0.0001^{* \star *}$ & \\
\hline 4 years & OL3 & $y=0.0107+8.5086 x$ & 0.9596 & $0.0006^{\star \star \star}$ & $0.0004^{\star \star \star}$ & \\
\hline 4 years & OL4 & $y=5.1820+9.6119 x$ & 0.9887 & $0.0000^{\star \star \star}$ & $0.0004^{\star \star *}$ & \\
\hline 8 years & OL5 & $y=2.1718+13.9909 x$ & 0.9888 & $0.0000^{\star \star *}$ & $0.0269^{*}$ & \\
\hline 10 years & OL6 & $\begin{array}{l}y=- \\
4.9583+13.2600 x\end{array}$ & 0.8841 & $0.0082^{* \star}$ & 0.1386 & $0.0002^{\star \star \star}$ \\
\hline 15 years & OL7 & $y=1.1083+11.4901 x$ & 0.9651 & $0.0004^{* * *}$ & $0.0064^{* *}$ & \\
\hline 20 years & OL8 & $\begin{array}{l}y=- \\
4.4219+13.6977 x\end{array}$ & 0.8716 & $0.0106^{*}$ & 0.1980 & $0.0005^{\star \star \star}$ \\
\hline $\begin{array}{l}\text { Natural } \\
\text { vegetation }\end{array}$ & OL9 & $y=5.3234+18.9851 x$ & 0.9810 & $0.0001^{* \star *}$ & & \\
\hline
\end{tabular}

ns Not significant, ${ }^{*} p<0.05$ Significant, ${ }^{* *} p<0.01$ Highly significant, ${ }^{* * *} p<$ 0.001 Very highly significant 
Table 2.

\begin{tabular}{lccccc}
\hline $\begin{array}{c}\text { Age of } \\
\text { abandoned } \\
\text { cropland }\end{array}$ & $\begin{array}{c}\text { Survey } \\
\text { plot } \\
\text { number }\end{array}$ & $\begin{array}{c}\text { Species } \\
\text { richness }\end{array}$ & $\begin{array}{c}\text { Species } \\
\text { evenness } \\
\text { (E) }\end{array}$ & $\begin{array}{c}\text { Shannon } \\
\text { index (H') }\end{array}$ & $\begin{array}{c}\text { Simpson } \\
\text { index (D) }\end{array}$ \\
\hline 3 years & OL1 & 28 & 0.613 & 2.044 & 0.744 \\
3 years & OL2 & 20 & 0.404 & 1.211 & 0.435 \\
4 years & OL3 & 29 & 0.734 & 2.471 & 0.856 \\
4 years & OL4 & 33 & 0.613 & 2.144 & 0.743 \\
8 years & OL5 & 45 & 0.797 & 3.014 & 0.884 \\
10 years & OL6 & 45 & 0.594 & 2.260 & 0.770 \\
15 years & OL7 & 40 & 0.579 & 2.138 & 0.760 \\
20 years & OL8 & 48 & 0.573 & 2.218 & 0.781 \\
Natural vegetation & OL9 & 66 & 0.592 & 2.480 & 0.762 \\
\hline
\end{tabular}


Table 3.

\begin{tabular}{|c|c|c|c|c|c|c|c|c|c|c|}
\hline Species & $\begin{array}{l}\text { Annual/ } \\
\text { Perennial/ } \\
\text { Life form }\end{array}$ & OL1 & OL2 & OL3 & OL4 & OL5 & OL6 & OL7 & OL8 & OL9 \\
\hline $\begin{array}{l}\text { Chrysocoma } \\
\text { ciliata }\end{array}$ & $\begin{array}{l}\text { Perennial } \\
\text { (Ch) }\end{array}$ & 10.0 & 35.0 & 0.5 & 1.0 & 10.0 & 5.0 & 40.0 & 25.0 & 5.0 \\
\hline $\begin{array}{l}\text { Cotula } \\
\text { nudicaulis }\end{array}$ & $\begin{array}{l}\text { Annual } \\
\text { (T) }\end{array}$ & & & 2.0 & 0.5 & 0.5 & & & 0.5 & 0.5 \\
\hline $\begin{array}{l}\text { Dicerothamnus } \\
\text { rhinocerotis }\end{array}$ & $\begin{array}{l}\text { Perennial } \\
(\mathrm{P})\end{array}$ & 25.0 & 2.0 & 5.0 & 0.5 & 0.5 & 15.0 & 15.0 & 5.0 & 2.0 \\
\hline $\begin{array}{l}\text { Dimorphotheca } \\
\text { cuneata }\end{array}$ & $\begin{array}{l}\text { Perennial } \\
(\mathrm{Ch})\end{array}$ & 3.0 & 0.5 & 0.5 & 1.0 & 5.0 & 25.0 & 10.0 & 2.0 & 10.0 \\
\hline $\begin{array}{l}\text { Erodium } \\
\text { moschatum }\end{array}$ & $\begin{array}{l}\text { Annual } \\
\text { (T) }\end{array}$ & 0.5 & 0.5 & 0.5 & 0.5 & 0.5 & $<0.1$ & & 0.5 & 0.5 \\
\hline $\begin{array}{l}\text { Euryops } \\
\text { laterifolius }\end{array}$ & $\begin{array}{l}\text { Perennial } \\
\text { (P) }\end{array}$ & 0.5 & & 0.5 & & & 0.5 & 0.5 & 0.5 & 10.0 \\
\hline $\begin{array}{l}\text { Helichrysum } \\
\text { hamulosum }\end{array}$ & $\begin{array}{l}\text { Perennial } \\
(\mathrm{P})\end{array}$ & 0.5 & $<0.1$ & & & 0.5 & 0.5 & 0.5 & 25.0 & 2.0 \\
\hline $\begin{array}{l}\text { Hordeum } \\
\text { murinum }\end{array}$ & $\begin{array}{l}\text { Annual } \\
(T)\end{array}$ & & 0.5 & 3.0 & 10.0 & 0.5 & & & & \\
\hline $\begin{array}{l}\text { Karoochloa } \\
\text { tenella }\end{array}$ & $\begin{array}{l}\text { Annual } \\
(T)\end{array}$ & & 0.5 & 5.0 & 0.5 & 1.0 & 0.5 & 0.5 & & \\
\hline $\begin{array}{l}\text { Medicago } \\
\text { polymorpha }\end{array}$ & $\begin{array}{l}\text { Annual } \\
(T)\end{array}$ & 1.0 & 3.0 & 10.0 & 20.0 & 0.5 & & & $<0.1$ & \\
\hline $\begin{array}{l}\text { Merxmuellera } \\
\text { stricta }\end{array}$ & $\begin{array}{l}\text { Perennial } \\
\text { (Ch) }\end{array}$ & & & & & & & $<0.1$ & 0.5 & 50.0 \\
\hline $\begin{array}{l}\text { Oedera } \\
\text { genistifolia }\end{array}$ & $\begin{array}{l}\text { Perennial } \\
\text { (Ch) }\end{array}$ & & & & & 0.5 & 0.5 & 5.0 & 0.5 & 2.0 \\
\hline $\begin{array}{l}\text { Pentaschistis } \\
\text { aristifolia }\end{array}$ & $\begin{array}{l}\text { Annual } \\
(\mathrm{T})\end{array}$ & 0.5 & 0.5 & 0.5 & 0.5 & 0.5 & 0.5 & 0.5 & 0.5 & 0.5 \\
\hline Poa bulbosa & $\begin{array}{l}\text { Annual } \\
(\mathrm{T})\end{array}$ & & & & & & 0.5 & & 5.0 & 2.0 \\
\hline Selago cf. rigida & $\begin{array}{l}\text { Perennial } \\
\text { (Ch) }\end{array}$ & 5.0 & 0.5 & 0.5 & 0.5 & & 0.5 & 5.0 & 0.5 & 0.5 \\
\hline
\end{tabular}

Nomenclature follows Germishuizen \& Meyer (2003). (P) = Phanerophyte, $(\mathrm{Ch})=$ Chamaephyte,$(\mathrm{T})=$ Therophyte 


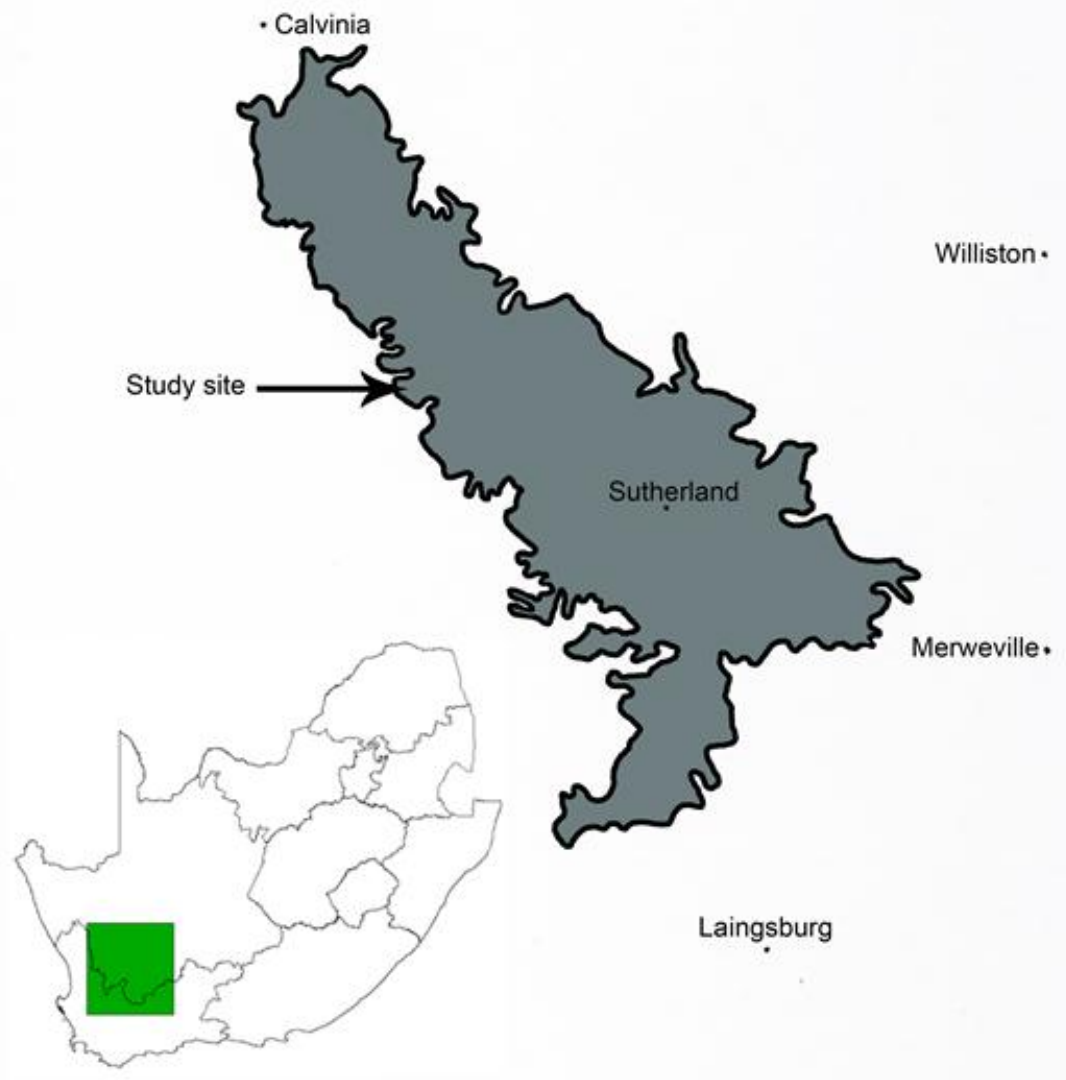

Figure 1. 

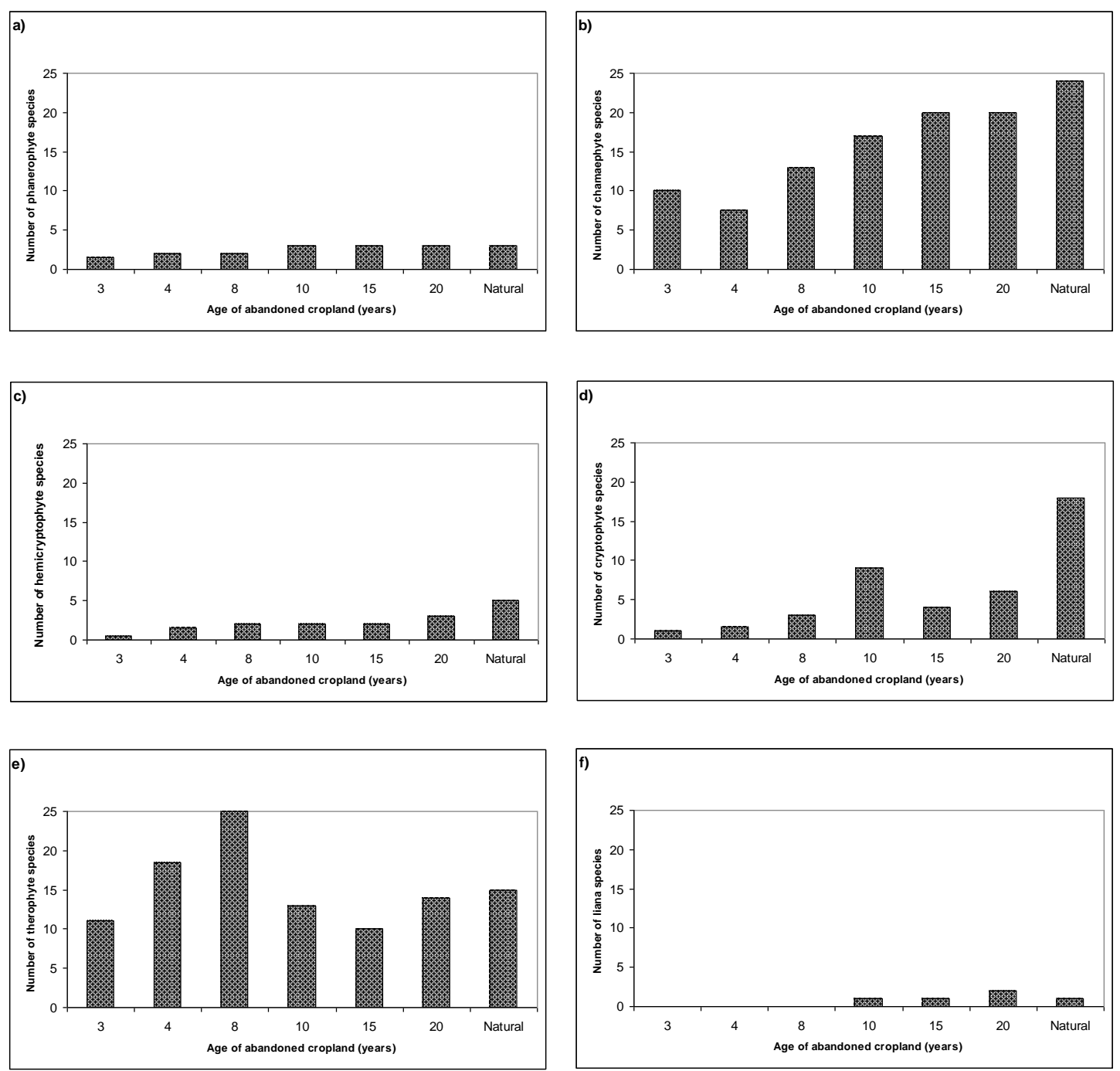

Figure 2 . 


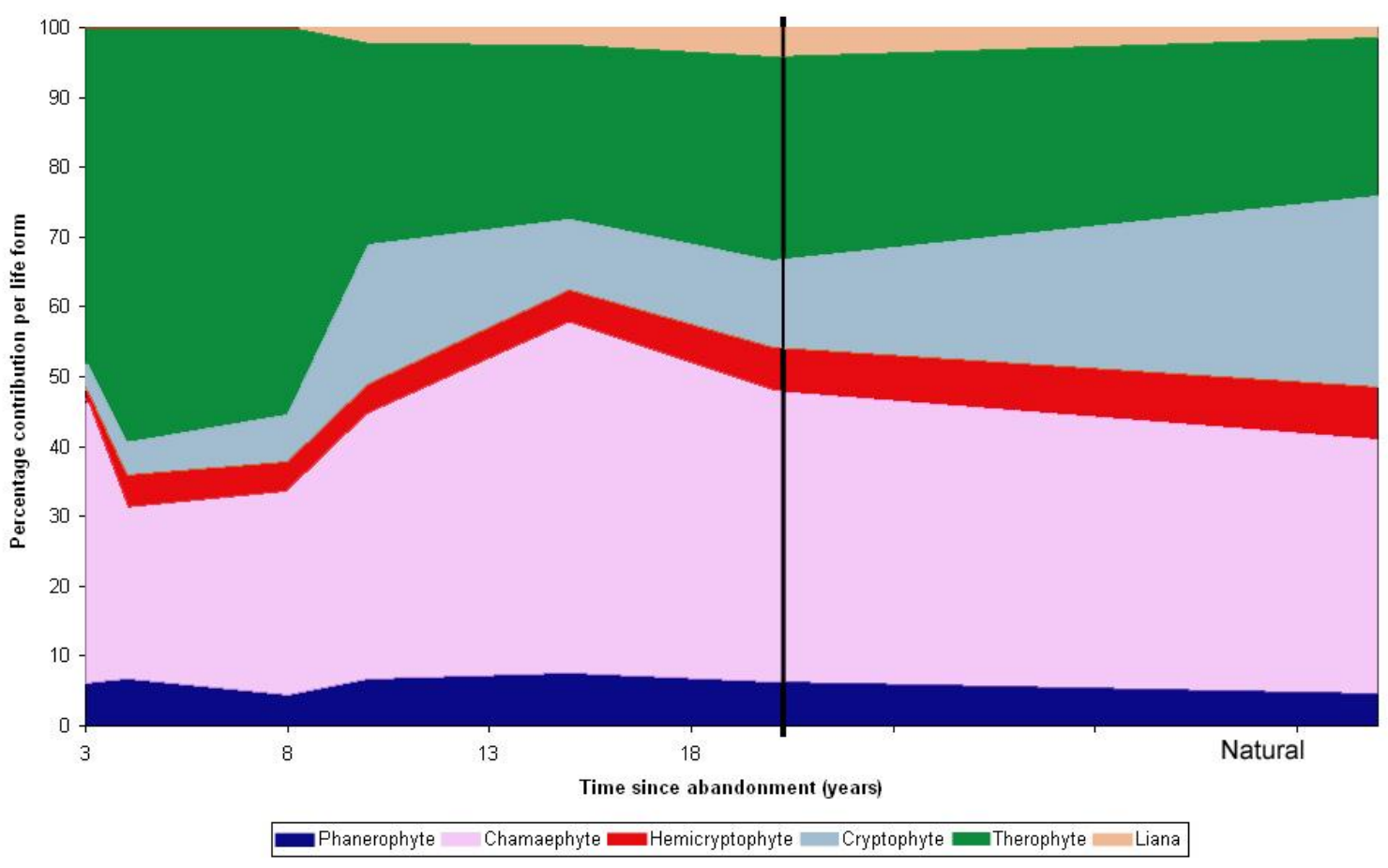

Figure 3.

34 


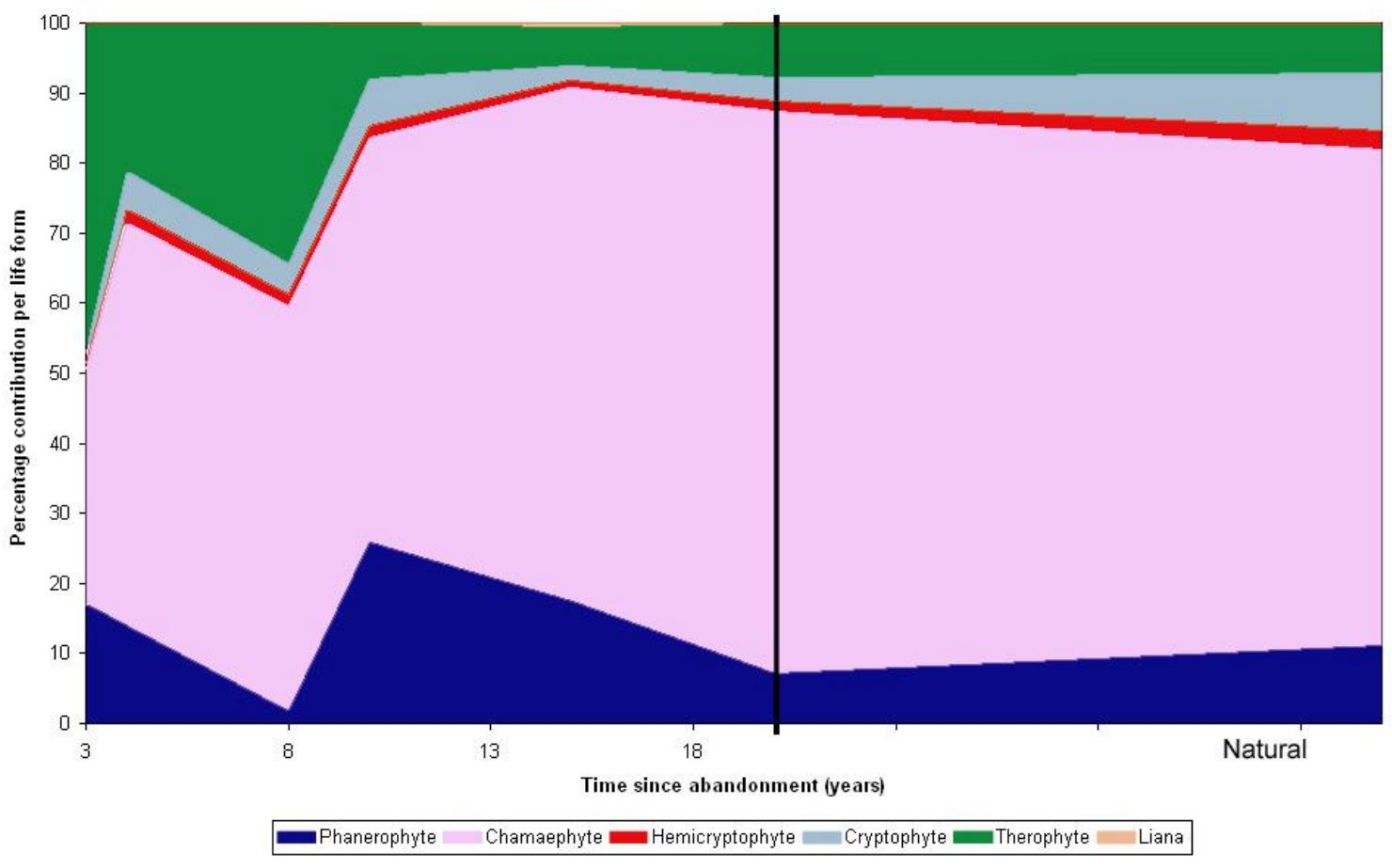

Figure 4.

35 


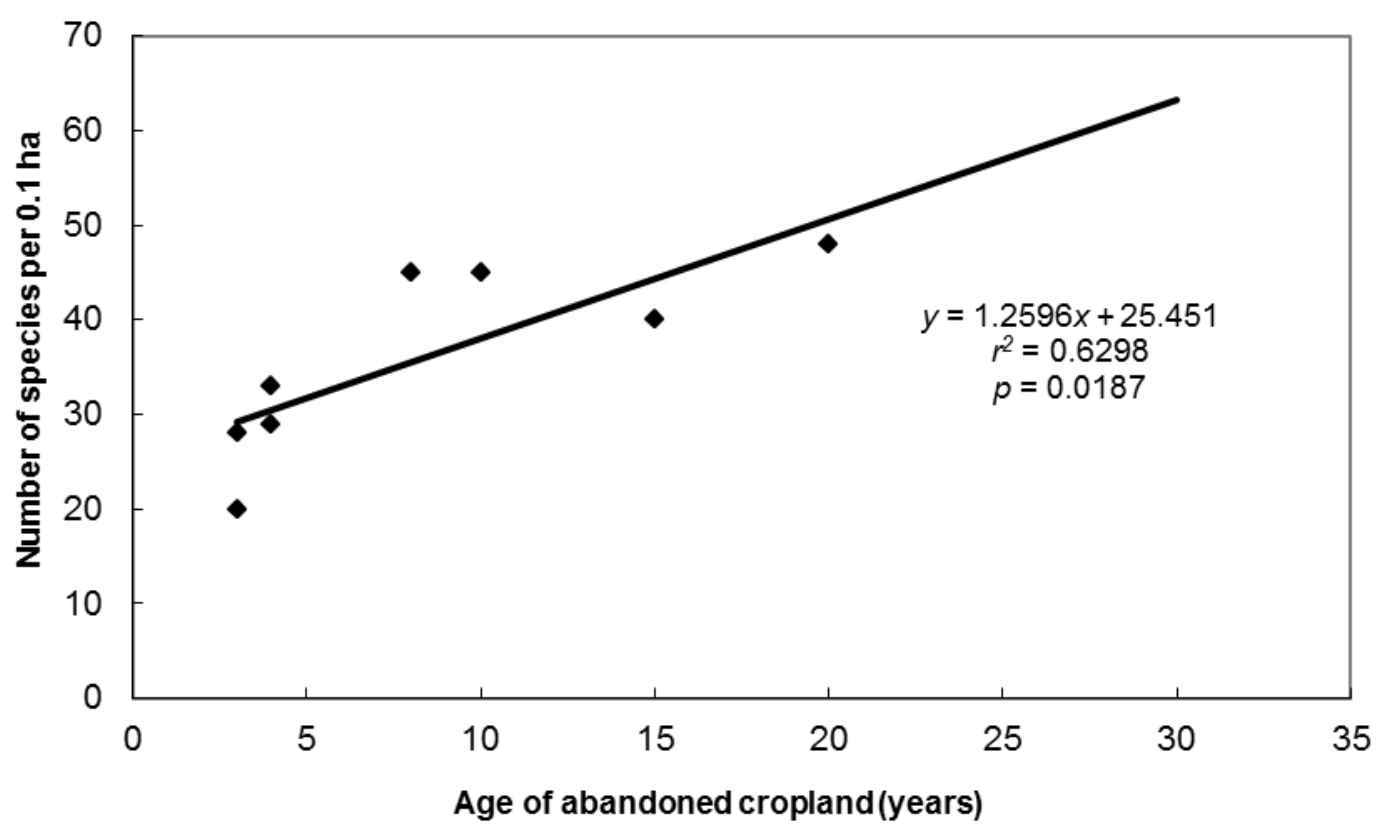

Figure 5. 


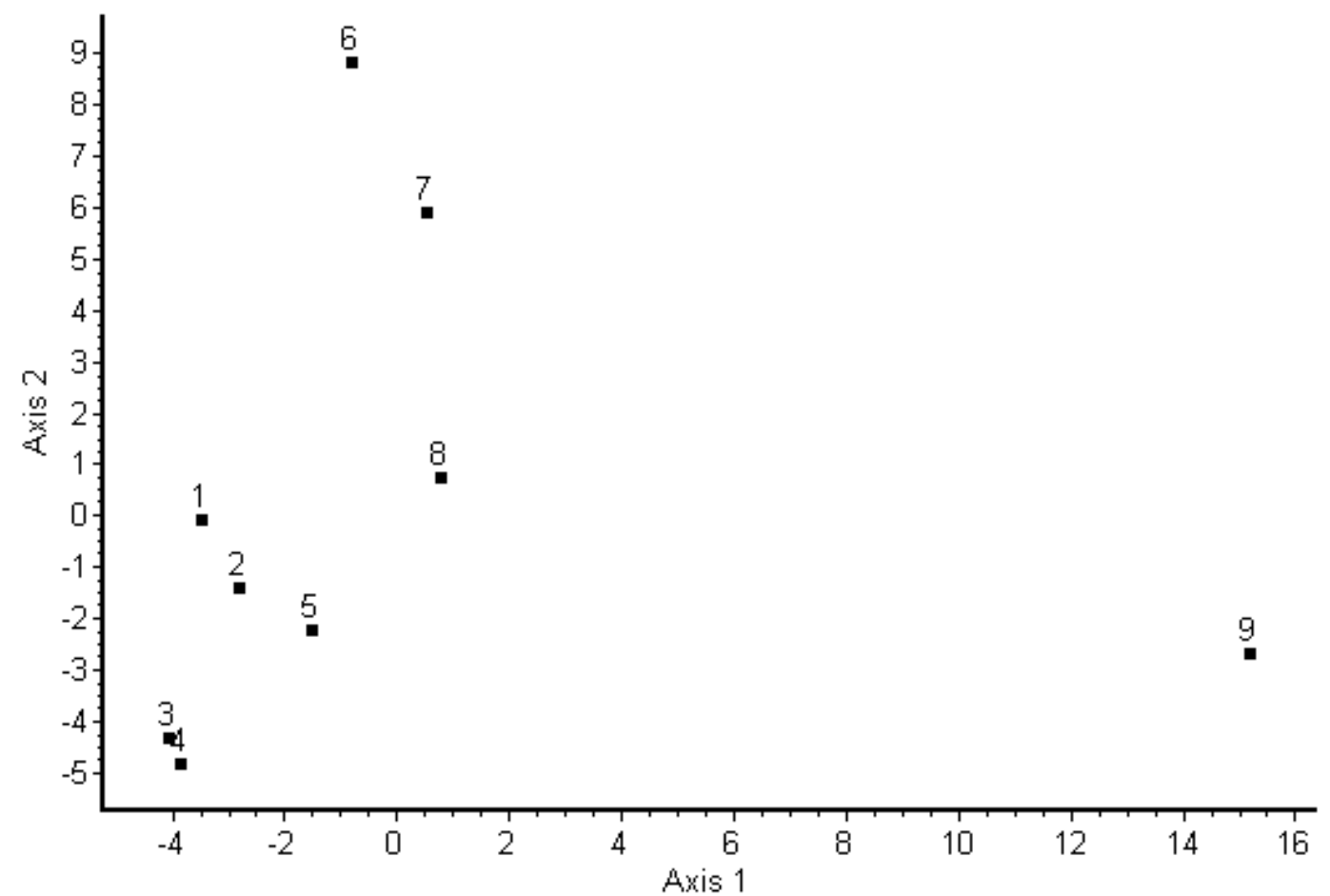

Figure 6. 